\title{
PERBAIKAN MUTU ORGANOLEPTIK IKAN ROA (Hemirhamphus sp.) ASAP MELALUI METODE PENGASAPAN RUANG TERTUTUP
}

\author{
Verly Dotulong $^{1}$ dan Lita A.D.Y Montolalu ${ }^{2}$ \\ ${ }^{1,2)}$ Program Studi Teknologi Hasil Perikanan FPIK Unsrat Manado. \\ Email: verlydotulong@yahoo.co.id
}

\begin{abstract}
ABSTRAK
Ikan julung-julung (Hermihampus sp.) asap dengan nama lokal ikan roa asap adalah salah satu jenis olahan ikan yang ada di Sulawesi Utara, jenis olahan ini mempunyai rasa yang khas keasap-asapan yang digemari oleh masyarakat bahkan sering dijadikan oleh-oleh khas Manado yang dibawa ke daerah lain. Ikan asap ini dihasilkan melalui kombinasi dua metode pengasapan yaitu pengasapan panas dan pengasapan dingin. Lokasi penelitian (pengolahan ikan asap) bertempat di desa Nain Kecamatan Wori Kabupaten Minahasa Utara Provinsi Sulawesi Utara yang secara geografis terletak di pesisir pantai dengan potensi perikanan laut yang potensial untuk dikembangkan, dimana $79 \%$ dari masyarakatnya berprofesi sebagai nelayan, dan sekitar 59\% adalah pengolah ikan roa asap, proses pengolahan ikan asap di daerah ini menggunakan ruang pengasapan terbuka yang sederhana. Penelitian ini bertujuan melihat pengaruh ruang pengasapan tertutup dan lama penyimpanan pada suhu ruang selama 10, 20 dan 30 hari terhadap mutu organoleptik ikan roa asap. Metode penelitian yang digunakan adalah metode eksploratif deskriptif yaitu mengumpulkan data fakta yang telah tersedia di lapangan melalui pencatatan dan pengamatan secara terperinci dan sistematik kemudian dilakukan analisa data berdasarkan data kualitatif dan kuantitatif. Hasil Penelitian menunjukkan bahwa pengasapan dengan ruang pengasapan tertutup yang dirancang oleh peneliti menghasilkan ikan roa asap dengan mutu organoleptik lebih tinggi selama penyimpanan pada suhu ruang dibandingkan dengan mutu ikan roa asap yang diasapi pada ruang pengasapan terbuka milik pengolah yang ada di desa Nain.
\end{abstract}

Kata Kunci: Ikan Roa Asap, Organoleptik, Ruang Pengasapan Tertutup.

\section{PENDAHULUAN}

Ikan roa atau julung-julung (Hermihampus sp.) asap adalah salah satu jenis olahan ikan yang ada di Sulawesi Utara. Ikan asap ini dihasilkan melalui kombinasi dua metode pengasapan yaitu pengasapan panas dan pengasapan dingin. Jenis olahan ini mempunyai rasa yang khas keasap-asapan yang digemari oleh masyarakat, bahkan sering dijadikan oleholeh khas dari Manado yang dibawa ke daerah lain. Ikan roa asap adalah ikan asap hasil kombinasi pengasapan panas dan dingin.

Desa Nain (lokasi penelitian) terletak di pulau Nain Kecamatan Wori Kabupaten Minahasa Utara. Bila berkunjung ke desa ini dari kota Manado maka transportasi yang digunakan adalah kapal kayu berukuran kecil yang menggunakan motor tempel dengan waktu tempuh \pm 3 jam. Masyarakat desa ini berjumlah $203 \mathrm{KK}$, yang bermata pencaharian sebagai nelayang baik nelayan penuh maupun sambilan (nelayan dan petani rumput laut) $180 \mathrm{KK}$ (79 $\%$ ), dan yang melakukan usaha pengolahan ikan roa asap berjumlah $120 \mathrm{KK}(59 \%)$. Pendidikan masyarakat nelayan dan pengolah ikan roa asap tergolong rendah yaitu rata-rata tamatan SD, dimana sebagian besar adalah keluarga penerima raskin. Fasilitas pendidikan yang ada di desa ini hanya $1 \mathrm{SD}$.

Usaha pengolahan ikan roa asap terletak di pesisir pantai dan memiliki potensi perikanan laut yang potensial untuk dikembangkan. Bahan baku yang digunakan didapat dari nelayan setempat yang juga adalah pengolah ikan roa asap, sehingga dari segi kualitas memiliki kelebihan yakni masih bermutu baik karena ikan baru tertangkap. Ikan roa yang diasap biasanya dijepit (digepe) dengan bilah bambu, dimana 1 jepitan berjumlah 20 ekor. Pengolah menjual ikan kepada tibo-tibo (pedagang) yang datang ke desa dengan harga yang tergolong murah yaitu Rp 17.500-20.000/jepit. Beberapa permasalahan yang ditemukan pada usaha pengolahan ini antara lain: tempat dan proses pengolahan yang tidak saniter, penggunan bahan pengasap kayu bakau yang merusak lingkungan, kurang baiknya proses produksi khususnya penggunaan ruang pengasapan dengan konstruksi terbuka. Ikan roa dikemas 
dengan karung plastik bekas dan harga jual yang masih rendah kepada tibo-tibo.

Berdasarkan permasalahan di atas maka peneliti melalui program Iptek bagi masyarakat (IbM) Kemenristekdikti tahun anggaran 2017 melaksanakan kegiatan pengadaan rumah pengasapan tertutup. Tujuan kegiatan ini adalah untuk meningkatkan mutu ikan roa asap yang dihasilkan oleh kelompok pengolah yang ada di desa Nain, sekaligus membantu meningkatkan pendapatan pengolah, karena ikan roa asap yang bermutu baik akan mempunyai harga jual yang tentu akan lebih baik.

\section{METODOLOGI PENELITIAN}

\section{Metode Penelitian}

Metode penelitian yang digunakan adalah metode eksploratif deskriptif, yaitu mengumpulkan data fakta yang telah tersedia di lapangan melalui pencatatan dan pengamatan secara terperinci dan sistematik kemudian dilakukan analisa data berdasarkan data kualitatif dan data kuantitatif (Sudjana dan Kusuma, 2004).

\section{Tempat dan Waktu Penelitian}

Lokasi Pengasapan ikan roa bertempat di desa Nain 1, Kecamatan Wori, Kabupaten Minahasa Tenggara, Provinsi Sulawesi Utara. Mutu organoleptik ikan roa asap dilakukan dengan menggunakan masyarakat sebagai panelis. Parameter mutu terdiri atas nilai kenampakan, bau, rasa dan tekstur dengan menggunakan score-sheet menurut SNI (2009). Kegiatan pelaksanaan penelitian hingga perampungan jurnal ini berlangsung selama 6 bulan mulai dari bulan Februari sampai dengan bulan September 2015.

\section{Bahan dan Alat}

Bahan baku yang digunakan dalam penelitian ini adalah ikan roa segar yang ditangkap oleh kelompok pengolah ikan roa asap dari desa Nain 1. Bahan tambahan adalah bambu untuk pembuatan penjepit, bahan bakar adalah kayu kelapa dan kayu mangga, rumah pengasapan struktur terbuka milik pengolah dan rumah pengasapan struktur tertutup yang dirancang oleh peneliti. Alat-alat yang digunakan untuk pengujian organoleptik adalah wadah tempat meletakkan sampel uji, air mineral untuk penetral rasa, pullpen dan lembar penilaian (score sheet).

\section{Perlakuan}

Perlakuan yang dirancang dalam penelitian ini adalah sebagai berikut:

$\mathrm{A}=$ Rumah pengasapan yang terdiri atas;

$\mathrm{A}_{1}=$ Rumah pengasapan terbuka (milik pengolah ikan roa asap (Gambar 1), ukuran PxLxT $=3 \times 4 \times 2,5 \mathrm{~m}$;

$\mathrm{A}_{2}=$ Rumah pengasapan tertutup (dibuat oleh peneliti) (Gambar 2), ukuran PxLxT = $3 \times 3 \times 3 \mathrm{~m}$;

$\mathrm{B}$ = Lama penyimpanan pada suhu ruang yang terdiri atas;

$\mathrm{B}_{1}=10$ hari;

$\mathrm{B}_{2}=20$ hari;

$\mathrm{B}_{3}=30$ hari.

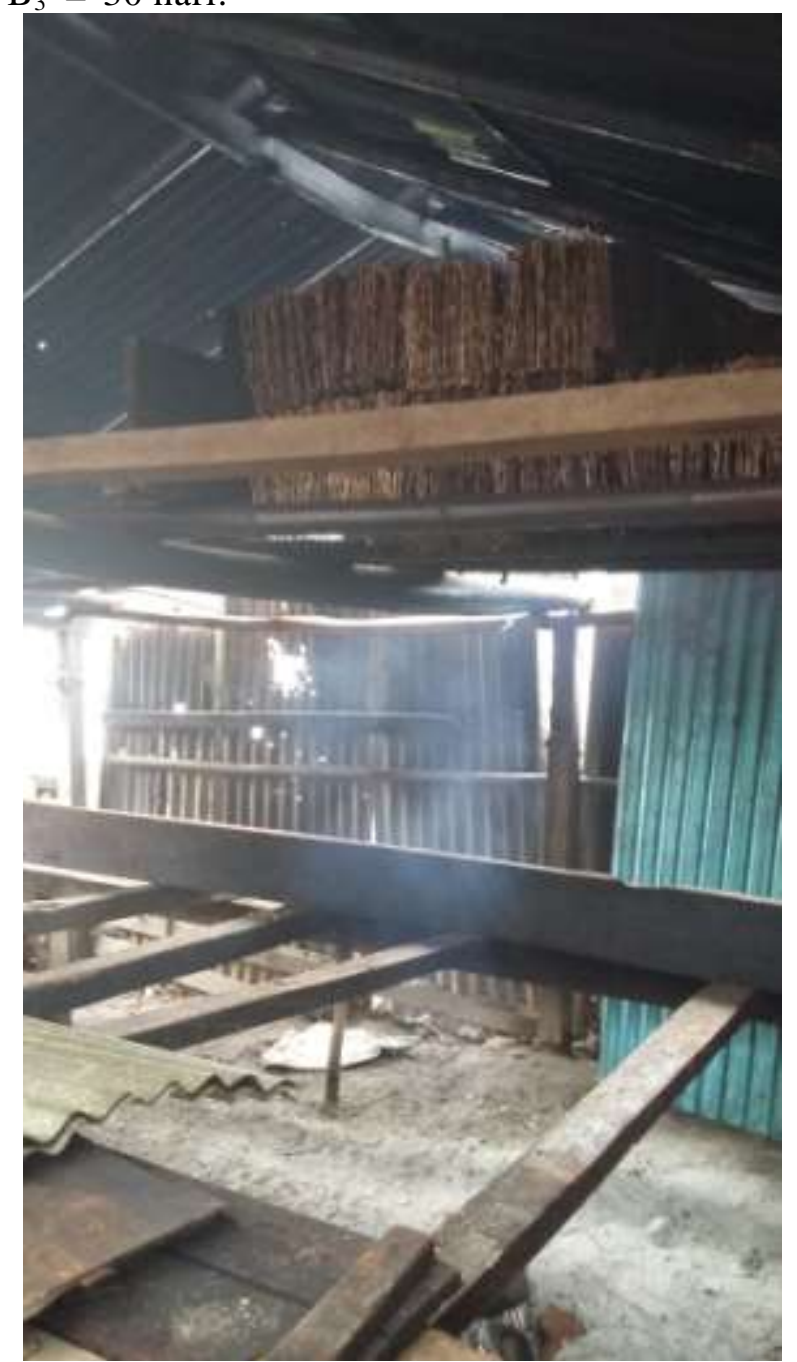

Gambar 1. Rumah pengasapan terbuka milik pengolah. 

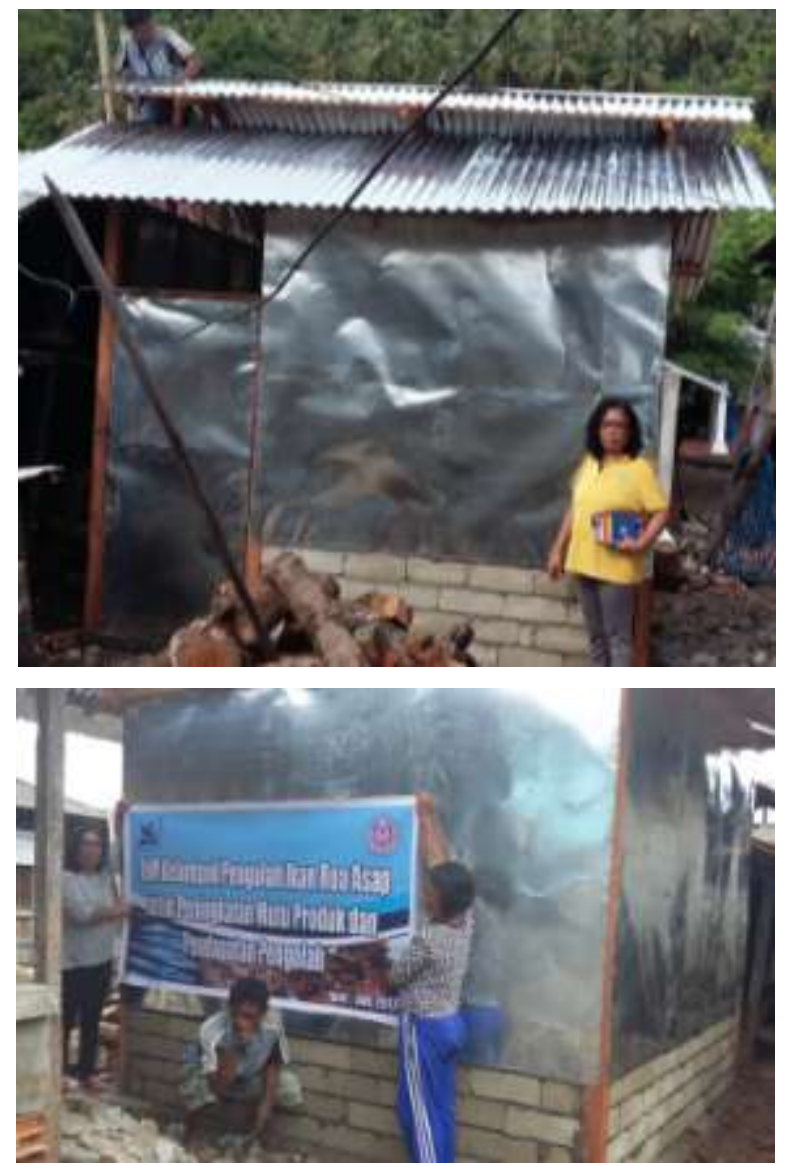

Gambar 2. Rumah pengasapan tertutup tampak depan dan samping.

\section{Prosedur Uji Organoleptik (SNI, 2009)}

Metode uji menggunakan skala angka 1 sebagai nilai terendah dan angka 9 sebagai nilai tertinggi. Batas penolakan untuk ikan asap ialah 7, artinya bila produk ini diuji memperoleh lebih kecil dari 7 maka produk tersebut dinyatakan tidak memenuhi standar mutu (ditolak).

\section{Analisa Data}

Analisa data pengujian organoleptik yaitu kenampakan, bau, rasa dan tekstur ditabulasi dan ditentukan nilai mutu ikan asap dengan mencari nilai rata-rata dari setiap panelis.

\section{HASIL DAN PEMBAHASAN}

\section{Organoleptik Kenampakan}

Kenampakan ikan roa asap yang diasapi dengan rumah pengasapan terbuka dan rumah pengasapan tertutup berturut-turut dapat dilihat pada Gambar 3 dan Gambar 4.
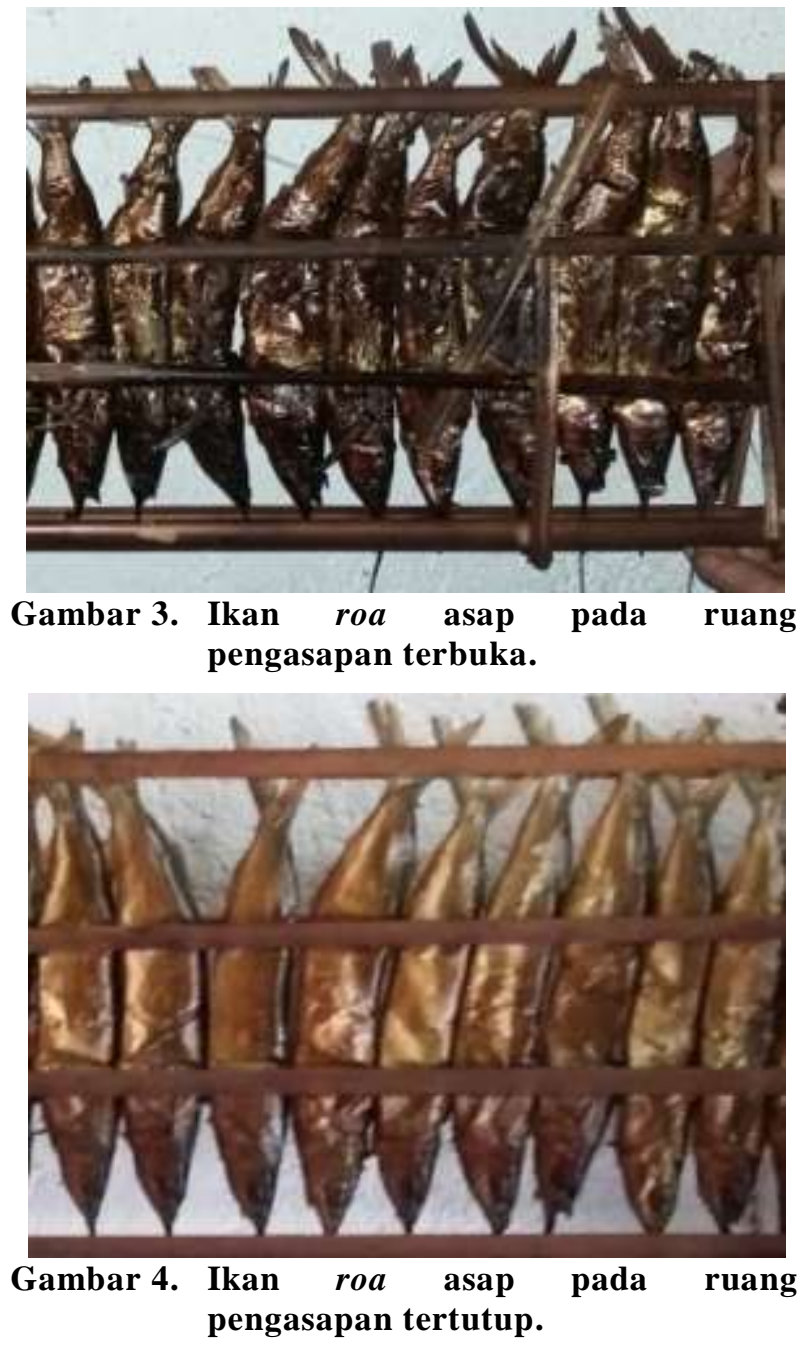

Hasil Penilaian organoleptik kenampakan ikan roa asap yang diasapi pada ruang pengasapan terbuka dan ruang pengasapan tertutup selama penyimpanan pada suhu ruang dapat dilihat pada Gambar 5.

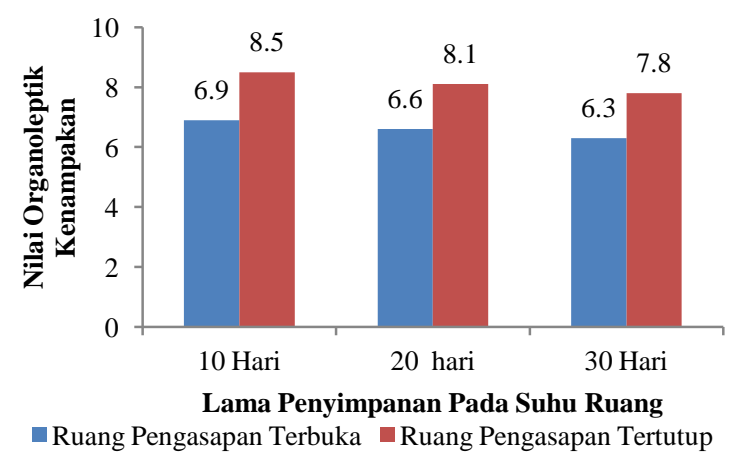

Gambar 5. Hasil penilaian organoleptik kenampan ikan roa asap selama penyimpanan suhu ruang.

Gambar 5, memperlihatkan bahwa nilai organoleptik kenampakan untuk ikan roa yang diasapi dalam ruang pengasapan terbuka lebih kecil dari 7, berturut-turut untuk lama penyim- 
panan 10, 20 dan 30 hari adalah 6,9; 6,6 dan 6,3 artinya tidak memenuhi standar mutu ikan asap (SNI, 2009), dan menurun selama penyimpanan dalam suhu ruang. Hal ini disebabkan karena pada ruang pengasapan terbuka panas dan asap tidak terkonsentrasi pada ikan yang diasapi karena ditiup oleh angin, selain itu karena lokasi tempat pengasapan terletak di pinggir pantai sehingga sering terjadi angin yang cukup kencang secara tiba-tiba yang menyebabkan bahan bakar menyala sehingga ikan asap menjadi hangus dimana bagian kulit berwarna hitam (Gambar 3). Ikan roa yang diasapi dalam ruang pengasapan tertutup yang dirancang peneliti menghasilkan ikan roa asap yang mempunyai nilai kenampakan lebih besar dari 7 sampai hari penyimpanan ke 14 artinya masih memenuhi standar mutu ikan asap menurut SNI (2009), Warna ikan roa asap yang diasapi dalam ruang pengasapan tertutup adalah kuning emas (Gambar 4). Hal ini disebabkan pada ruang pengasapan tertutup asap dan panas terkonsentrasi melewati produk (ikan) yang sedang diasapi sehingga ikan lebih cepat masak, kadar air berkurang dan komponen dalam asap menyebabkan kulit ikan yang diasapi berwarna kuning emas. Winarno $d k k$., (1980) menyatakan bahwa komponen dalam asap juga dapat berfungsi sebagai pemberi warna pada ikan asap, sehingga ikan yang telah diawetkan dengan proses pengasapan berwarna kuning keemasan dan dapat membangkitkan selera konsumen. Menurut Moeljanto (1992), warna yang dikendaki oleh konsumen sebagai warna ideal dari ikan hasil proses pengasapan adalah warna kuning emas kecoklatan. Hal ini disebabkan oleh adanya reaksi kimia dari persenyawaan dalam asap yaitu formaldehid dengan fenol yang menghasilkan lapisan damar tiruan pada permukaan kulit ikan. Sulitijowati $d k k$, (2011), menyatakan bahwa ikan asap yang bermutu baik akan mempunyai warna kuning keemasan.

\section{Organoleptik Bau}

Nilai rata-rata organoleptik bau ikan roa asap dapat dilihat pada Gambar 6 di bawah ini. Data pada Gambar 6 menunjukkan bahwa nilai organoleptik bau ikan roa asap yang diasapi pada ruang pengasapan terbuka berturut-turut untuk lama penyimpanan 10, 20 dan 30 hari adalah 7,3; 7,2 dan 7,2. Hal ini mengindikasikan bahwa bau ikan roa asap adalah harum asap kurang, tanpa bau tambahan mengganggu. Nilai ini lebih rendah dibandingkan dengan nilai organoleptik bau ikan roa yang diasapi pada ruang pengasapan tertutup berturut-turut untuk lama penyimpanan 10, 20 dan 30 hari adalah 8,1; 7,8 dan 7,5. Hal ini mengindikasikan bahwa bau ikan roa asap adalah harum asap cukup, tanpa bau tambahan mengganggu (SNI, 2009).

Nilai organoleptik bau yang lebih tinggi pada ikan roa yang diasap pada rumah pengasapan tertutup disebabkan karena panas dan asap lebih banyak terkonsentrasi melewati ikan yang sedang diasapi dibandingkan dengan pada ruang pengasapan terbuka, dimana panas dan asap tersebut menyebar dan tidak maksimal melewati ikan yang sedang diasapi karena ditiup angin. Marassebesy (2011), menyatakan bahwa panas dapat menyebabkan kadar air berkurang, juga komponen asap yang mengendap pada ikan selama pengasapan bersifat antibakteri sehingga mempengaruhi jumlah pertumbuhan bakteri dalam proses pengasapan ikan. Selanjutnya menurut Winarno, dkk., (1980), proses pemanasan dapat membunuh bakteri dan panas yang dihasilkan dapat mengeringkan bahan yang diasapi sehingga lebih awet. Menurut Saparinto (2010), faktor yang mempengaruhi mutu ikan asap diantaranya berkurangnya kadar air sampai di bawah $40 \%$, adanya senyawa-senyawa di dalam asap kayu yang dapat menghambat pertumbuhan bakteri pembusuk dan terjadinya koagulasi protein pada permukaan ikan yang mengakibatkan jaringan pengikat menjadi lebih kuat dan kompak sehingga tahan terhadap serangan bakteri.

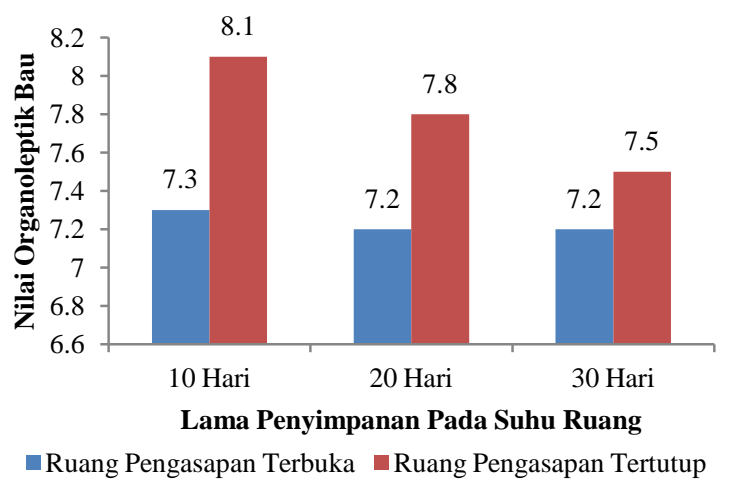

Gambar 6. Hasil penilaian organoleptik bau ikan roa asap selama penyimpanan suhu ruang.

Senyawa kimia dalam asap kayu yang bersifat sebagai antimikroba adalah berbagai macam aldehida, alkohol, keton dan sebagainya (Susatyo, 2004). Terhambatnya perkembangan 
mikroba pembusuk menyebabkan bau ikan asap akan lebih baik. Widiastuti (2007) menyatakan kehadiran mikroorganisme pada ikan mengakibatkan perubahan bau, bau tersebut timbul akibat timbulnya amoniak $\left(\mathrm{NH}_{3}\right)$ pada degradasi protein dan gas $\mathrm{H}_{2} \mathrm{~S}$ pada degradasi protein yang mengandung unsur sulfur oleh bakteri pembentuk gas $\mathrm{H}_{2} \mathrm{~S}$.

\section{Organoleptik Rasa}

Nilai rata-rata organoleptik rasa ikan roa asap dapat dilihat pada Gambar 7 di bawah ini. Data pada Gambar 7 menunjukkan bahwa nilai organoleptik rasa ikan roa asap yang diasapi pada ruang pengasapan terbuka berturut-turut untuk lama penyimpanan 10, 20 dan 30 hari adalah 7,3; 7,1 dan 7,1. Hal ini mengindikasikan bahwa rasa ikan roa asap adalah enak namun kurang gurih hal ini kemungkinan disebabkan karena warna ikan roa sedikit hitam karena agak hangus, menimbulkan sedikit rasa pahit sehingga mengurangi rasa gurih. Nilai ini lebih rendah dibandingkan dengan nilai organoleptik rasa ikan roa yang diasapi pada ruang pengasapan tertutup berturut-turut untuk lama penyimpanan 10, 20 dan 30 hari adalah 8,3; 7,6 dan 7,6. Hal ini mengindikasikan bahwa rasa ikan roa asap adalah enak dan gurih (SNI, 2009). Menurut Wibowo (1996), kriteria mutu organoleptik untuk rasa ikan asap adalah enak, rasa asap terasa lembut sampai tajam tanpa rasa getir atau pahit, dan tidak berasa tengik.

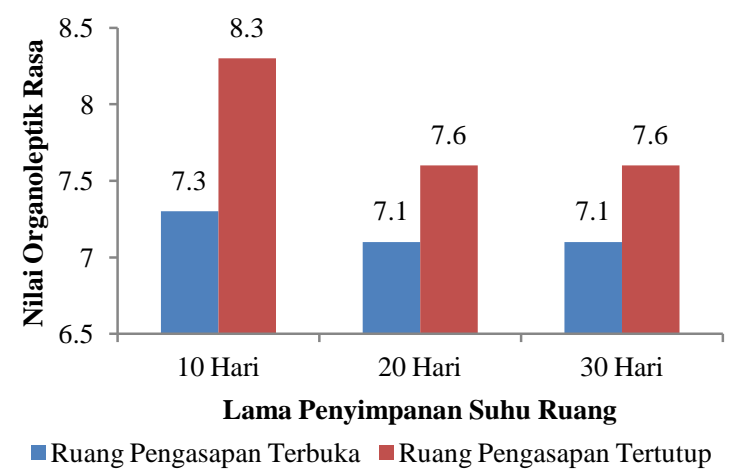

Gambar 7. Hasil penilaian organoleptik rasa ikan roa asap selama penyimpanan suhu ruang.

Nilai organolptik rasa yang lebih rendah pada ikan roa yang diasapi pada rumah pengasapan terbuka disebabkan karena panas dan asap menyebar tidak maksimal melewati ikan yang sedang diasapi karena ditiup angin, dibandingkan dengan pada ruang pengasapan tertutup dimana panas dan asap tersebut terkonsentrasi melewati ikan yang sedang diasapi. Panas dapat menyebabkan kadar air berkurang sehingga menghambat pertumbuhan mikroba pembusuk, sedangkan asap mengandung senyawa-senyawa kimia yang besifat antibakteri. Menurut Winarno, $d k k$., (1980), proses pemanasan dapat membunuh bakteri dan panas yang dihasilkan dapat mengeringkan bahan yang diasapi sehingga lebih awet. Selanjutnya Palm, et al. (2011) menyatakan bahwa pada proses pengasapan ikan terjadi penetrasi senyawa volatil pada ikan yang dihasilkan dari pembakaran kayu. Komponen asap dapat memperpanjang masa simpan karena mempunyai aktivitas antibakteri (Abologba dan Igbinevbo, 2010), juga dapat menghasilkan produk dengan rasa dan aroma yang spesifik (Bower, et al., 2009).

\section{Organoleptik Tekstur}

Nilai rata-rata organoleptik tekstur ikan roa asap dapat dilihat pada Gambar 8 di bawah ini. Data pada Gambar 8 menunjukkan bahwa nilai organoleptik tekstur ikan roa asap yang diasapi pada ruang pengasapan terbuka berturut-turut untuk lama penyimpanan 10, 20 dan 30 hari adalah 7,2; 7,1 dan 7,1, sedangkan nilai organoleptik tekstur ikan roa asap yang diasapi pada ruang pengasapan tertutup adalah 8,$1 ; 7,7$; dan 7,5 .

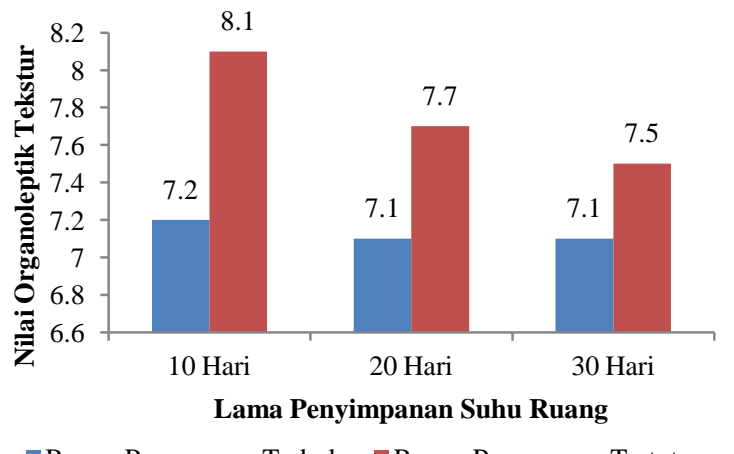

- Ruang Pengasapan Terbuka $\square$ Ruang Pengasapan Tertutup

Gambar 8. Hasil penilaian organoleptik tekstur ikan roa asap selama penyimpanan suhu ruang.

Dari data di atas dapat dilihat bahwa nilai organoleptik tekstur ikan roa asap yang diasapi pada ruang pengasapan terbuka selama penyimpanan suhu kamar lebih rendah dibandingkan dengan nilai organoleptik tekstur pada ikan roa asap yang diasapi pada ruang pengasapan tertutup. Nilai ini menunjukkan bahwa tekstur ikan roa asap padat, kompak, kering, antar jaringan erat, sejajar dengan nilai organoleptik lainnya yang menunjukkan bahwa 
ikan roa asap yang diasap pada ruang pengasapan tertutup lebih unggul. Panas dan asap yang terkonsentrasi melewati produk yang diasapi menyebabkan kadar air berkurang dan pertumbuhan mikroba pembusuk terhambat. Nilai tekstur suatu produk dipengaruhi juga oleh kadar air daging ikan yang segar, menghambat pertumbuhan mikroba, sehingga menyebabkan daging ikan lebih kompak, tekstur lebih baik dan disukai panelis. Wibowo (2000) menyatakan bahwa keadaan tekstur bahan merupakan suatu sifat dari bahan pangan yang paling penting. Produk yang memiliki tekstur yang paling baik memiliki mutu yang baik. Adapun kadar air dapat mempengaruhi tekstur dari suatu produk (Sakidja, 1989).

\section{KESIMPULAN}

Ikan roa asap yang diasapi pada ruang pengasapan tertutup selama penyimpanan suhu ruang mempunyai nilai organoleptik baik kenampakan, bau, rasa dan tekstur lebih tinggi daripada ikan roa asap yang diasapi pada ruang pengasapan terbuka.

\section{DAFTAR PUSTAKA}

Abolagba O.J and Igbinevbo E.E. 2010. Microbial load of fresh and smoked fish marketed in Benin metropolis Nigeria. Journal of Fisheries and Hydrobiology 5 (2): 99-104.

Bower C.K, Hietala K.A, Oliveira A.C. Mand Wu T.H. 2009. Stabilizing Oils from smoked Pink Salmon
(Oncorhynchus gorbuscha). Journal of Food Science 74(3): 248-257.

Standard Nasional Indonesia ((SNI). 2009. Ikan Asap Bagian 1. Spesifikasi SNI 27 25.1:2009. Badan Standarisasi Indonesia.

Sudjana, N dan A. Kusuma. 2004. Proposal Penelitian di Perguruan Tinggi. Sinar Baru Algensindo. Bandung.

Marassebesy, Ismael. 2011. Aplikasi Asap Cair dalam Pengolahan Ikan Tongkol (Eutynnus affinis) Asap (Aplied of Liquid Smoked in Little Tuna Fish Eutynnus affinis of Smoke Processing).

Moeljanto, 1992. Pengawetan dan Pengolahan Hasil Perikanan. Penebar Swadaya, Jakarta.

Winarno F.G, Fardiaz S, dan Fardiaz D. 1980. Pengantar Teknologi Pangan. Gramedia. Jakarta.

Saparinto, Cahyo. 2010. Usaha Ikan Konsumsi di Lahan $100 \mathrm{~m}^{2}$. Penebar Swadaya. Jakarta.

Sulistijowati R.S, Otong Suhara D,Jetty Nurhayati, Eddy Afrianto, Zalinar Udin. 2011. Mekanisme Pengasapan Ikan. UNPAD Press.

Susatyo. 2004. Kajian Beberapa Aspek Pengolahan Ikan Secara Tradisional dalam Upaya Peningkatan Mutu Produk Perikanan di Kabupaten Jepara. www.eprints.undip.ac.id-jurnal ikan asap.

Wibowo, S. 1996. Industri Pemindangan Ikan. Penebar Swadya.

Wibowo, S. 2000. Industri Pengasapan Ikan. Penebar Swadaya. Jakarta.

Widiastuti, I.M. 2007. Sanitasi dan Mutu Kesegaran Ikan Konsumsi pada Pasar Tradisional di Kotamadya Palu. Jurnal. Agroland 14 (1):77-81 ISSN: 0854-641X.

Sakidja,1989. Kimia Pangan. Direktorat Pendidikan dan Kebudayaan Direktorat Jendral Pendidikan Tinggi. Jakarta. 